\title{
Comparative analysis of differentially expressed sequence tags of sweet orange and mandarin infected with Xylella fastidiosa
}

\author{
Alessandra A. de Souza ${ }^{1}$, Marco A. Takita ${ }^{1,2}$, Helvécio D. Coletta-Filho ${ }^{1}$, Magnólia A. Campos ${ }^{3}$, \\ Juliana E.C. Teixeira ${ }^{4}$, Maria Luísa P.N. Targon ${ }^{1}$, Eduardo F. Carlos ${ }^{1}$, Juliano F. Ravasi ${ }^{5}$, \\ Carlos N. Fischer ${ }^{5}$ and Marcos A. Machado ${ }^{1}$ \\ ${ }^{1}$ Centro APTA Citros Sylvio Moreira, Instituto Agronômico de Campinas, Cordeirópolis, SP, Brazil. \\ ${ }^{2}$ Centro de Pesquisa e Desenvolvimento de Recursos Genéticos Vegetais, Campinas, SP, Brazil. \\ ${ }^{3}$ Departamento de Biologia, Universidade Federal de Lavras, Lavras, MG, Brazil. \\ ${ }^{4}$ Departamento de Genética e Fitopatologia, Escola Superior de Agricultura Luiz de Queiroz, \\ Universidade de São Paulo, Piracicaba, SP, Brazil. \\ ${ }^{5}$ Departamento de Estatística, Matemática Aplicada e Computação, \\ Instituto de Geociências e Ciências Exatas, Universidade Estadual Paulista, Rio Claro, SP, Brazil.
}

\begin{abstract}
The Citrus ESTs Sequencing Project (CitEST) conducted at Centro APTA Citros Sylvio Moreira/IAC has identified and catalogued ESTs representing a set of citrus genes expressed under relevant stress responses, including diseases such as citrus variegated chlorosis (CVC), caused by Xylella fastidiosa. All sweet orange (Citrus sinensis L. Osb.) varieties are susceptible to $X$. fastidiosa. On the other hand, mandarins ( $C$. reticulata Blanco) are considered tolerant or resistant to the disease, although the bacterium can be sporadically detected within the trees, but no disease symptoms or economic losses are observed. To study their genetic responses to the presence of $X$. fastidiosa, we have compared EST libraries of leaf tissue of sweet orange Pêra IAC (highly susceptible cultivar to $X$. fastidiosa) and mandarin 'Ponkan' (tolerant) artificially infected with the bacterium. Using an in silico differential display, 172 genes were found to be significantly differentially expressed in such conditions. Sweet orange presented an increase in expression of photosynthesis related genes that could reveal a strategy to counterbalance a possible lower photosynthetic activity resulting from early effects of the bacterial colonization in affected plants. On the other hand, mandarin showed an active multi-component defense response against the bacterium similar to the non-host resistance pattern.
\end{abstract}

Key words: ESTs, citrus variegated chlorosis, biotic stress, CitEST, phytopathogen.

Received: July 24, 2006; Accepted: March 6, 2007.

\section{Introduction}

Citrus is one of the most important crops in Brazil. The State of São Paulo is responsible for $80 \%$ of the domestic production of fresh fruit and $70 \%$ of the world production of concentrated orange juice. However, the Brazilian citrus industry faces constant challenges. The production is mostly conducted without irrigation and the industry is affected by many diseases and pests (Fernandes-Jr, 2003).

The citrus variegated chlorosis, caused by Xylella fastidiosa, is currently one of the most limiting diseases af-

Send correspondence to Alessandra Alves de Souza. Centro APTA Citros Sylvio Moreira, Instituto Agronômico de Campinas, Rod. Anhanguera km 158, Caixa Postal 4, 13490-970 Cordeirópolis, SP, Brazil. E-mail: alessandra@ centrodecitricultura.br. fecting the groves. The annual loss due to $\mathrm{CVC}$ is more than the U $\$ 100$ million spent on chemical control of the vectors (sharpshooters), pruning infected branches and trees, and replacing old orchards (Fernandes-Jr, 2003). Genetic control is still not feasible because all varieties of sweet orange (C. sinensis $\mathrm{L}$. Osb.) used for juice production are highly susceptible to the disease. CVC diseased plants have a strong correlation between symptoms and disturbance caused by water stress, which is in accord with the hypothesis of xylem blockage caused by X. fastidiosa (Machado et al., 1994). On the other hand, mandarins and some hybrids with sweet orange seem to be tolerant or resistant to $X$. fastidiosa. Genetic mapping using these hybrids has revealed a complex inheritance to the resistance (Oliveira et al., 2005). However, there is little information about mo- 
lecular mechanisms that take place in the interaction between resistant plants and the bacterium.

The use of gene tags for evaluating the response to infections in plants represents a new approach in studies of plant-pathogen interactions (Lee et al., 2004). The identification and analysis of genes that are up or down expressed in the affected plants is thus an initial step that could help in the understanding of the entire mechanism of plant defense response. This knowledge may lead to a generation of disease-resistant plants.

The generation and analysis of expressed sequence tags (ESTs) have been employed in genomic research, especially for research with plant species with large genome sizes. The subsequent analysis of the ESTs has become a popular method for examining the spatial or temporal pattern for gene expression in many plants (Lee et al., 2004).

To understand the plant defense mechanism activated in response to the infection of $X$. fastidiosa, we ran a comparative analysis of gene expression profiles of the resistant 'Ponkan' mandarin (Citrus reticulata) and the susceptible 'Pêra IAC' sweet orange (Citrus sinensis) under the presence of the pathogen.

\section{Material and Methods}

\section{Xylella fastidiosa inoculum and monitoring of the bacterial infection}

Four plants, six months of age, of 'Ponkan' mandarin and 'Pera IAC' sweet orange grafted on Rangpur lime, were artificially inoculated by needle prick with $50 \mu \mathrm{L}$ suspension $\left(10^{10}\right.$ cells $\left.\mathrm{mL}^{-1}\right)$ of $X$. fastidiosa strain $9 \mathrm{a} 5 \mathrm{c}$ in PBS buffer. Negative controls of 'Ponkan' mandarin and 'Pera' sweet orange were mock-inoculated with PBS buffer. The plants were maintained in a growth chamber (Conviron PGW36, Winnipeg, Canada) with photoperiod of $16 \mathrm{~h}$. The range of temperature was from $25{ }^{\circ} \mathrm{C}$ to $28^{\circ} \mathrm{C}$.

The $X$. fastidiosa infection was monitored at two, four, and eight weeks after inoculation of the plants by PCR using the specific CVC1 and 272-2 int primers, according to Pooler and Hartung (1995) procedures. Total DNA was extracted from petioles and midribs using a CTAB method adapted from Murray and Thompson (1980). Briefly, $250 \mathrm{mg}$ of tissues were ground in liquid nitrogen and added to a $1.5 \mathrm{~mL}$ tube containing $600 \mu \mathrm{L}$ of extraction buffer (CTAB 5\%, NaCl 5 M, Tris-HCl pH $7.51 \mathrm{M}$, EDTA 0.5 M, and $\beta$-mercapto-ethanol $140 \mathrm{mM}$ ). The samples were incubated at $60^{\circ} \mathrm{C}$ for $30 \mathrm{~min}$ followed by extraction with chloroform:isoamilic alcohol (24:1). The DNA was precipitated using $800 \mu \mathrm{L}$ of ETOH $100 \%$ which was pelleted by centrifugation at $12,000 \mathrm{x}$ g for $10 \mathrm{~min}$. The DNA samples were solubilized in $50 \mu \mathrm{L}$ of $1 / 10 \mathrm{TE}(1 \mathrm{mM}$ Tris- $\mathrm{HCl} \mathrm{pH}$ 8.0; $0.1 \mathrm{mM}$ EDTA) containing $10 \mu \mathrm{g} / \mu \mathrm{L}$ RNAse DNA free and used for PCR analysis. The PCR amplifications were performed in a volume of $25 \mu \mathrm{L}$, which contained
$0.1 \mathrm{v} / \mathrm{v}$ of $10 \mathrm{X}$ buffer, $2.5 \mathrm{mM}$ of $\mathrm{MgCl}_{2}, 2.5 \mathrm{mM}$ of each dNTPs (Invitrogen Corp., San Diego, USA), 20 ng of CVC-1 and 272-2 int primers, 20 ng of total DNA, and 1.5 units of Taq DNA polymerase (Invitrogen Corp., San Diego, USA). A PTC100 thermocycler (MJ Research INC, Massachusetts, USA) was programmed starting with a initial denaturation step at $94{ }^{\circ} \mathrm{C}$ for 3 min followed by 36 cycles of: denaturation at $94^{\circ} \mathrm{C}$ for $45 \mathrm{~s}$, annealing at $60^{\circ} \mathrm{C}$ for $45 \mathrm{~s}$, elongation at $72^{\circ} \mathrm{C}$ for $45 \mathrm{~s}$, and a final extension incubation of $5 \mathrm{~min}$ at $72{ }^{\circ} \mathrm{C}$. Aliquots of $10 \mu \mathrm{L}$ from the amplification reactions were subjected to gel electrophoresis in $1.0 \%$ agarose. The gels were stained with ethidium bromide and examined under ultra-violet light.

Eleven weeks after the inoculation, the $X$. fastidiosa cells were recovered on PW medium (Davis et al., 1981) from the plants used for RNA extraction for the cDNA library construction. Petioles and midribs were aseptically ground in PBS and the suspension was spread on PW medium. The first colonies were observed between 10 to 15 days after inoculation.

\section{Leaf sampling for cDNA library}

Thirty days after inoculation, a bulk of leaves was collected for cDNA library preparation from the two plants within each species that tested positive for the presence of $X$. fastidiosa in PCR. Young but expanded leaves were collected and immediately put in liquid nitrogen. Afterwards, the material was stored at $-80^{\circ} \mathrm{C}$ until RNA extraction.

Total RNA was extracted using Trizol reagent (Invitrogen). The Poly(A+) RNA was isolated from $1 \mathrm{mg}$ of total RNA with the polyATtract mRNA Isolation System (Promega Corporation, Madison, WI). The SuperScript Plasmid System with Gateway Technology for cDNA Synthesis and Cloning (Invitrogen) was used for the library construction. All the steps were done according to the manufacturers' instructions.

The sequencing reactions were performed using the Big Dye Terminator DNA sequencing Kit (Applied Biosystems). Sequencing was done in the ABI 3730 (Applied Biosystems).

\section{In silico hybridization and functional annotation}

For comparison of the libraries (in silico hybridization) the reads of both cDNA libraries were analyzed and assembled using the Phred and Phrap programs (Ewing and Green, 1998; Ewing et al., 1998) with the default parameters. The resulting ace file was parsed with a homemade perl script, which extracted the identification of the contig together with the composing reads. The resulting file was submitted to a web implementation (http://gbirc.rc.unesp. br/jXPAnalysis/) of the Winflat software (Audic and Claverie, 1997). The statistical cutoff was set to $95 \%$ and the sequences of the significantly differentially expressed contigs were compared with the sequences of the nonredundant database of the National Center for Biological 
Information (NCBI) using the BlastX tool (Altschul et al., 1997). The functional categorization of sweet orange and mandarin putative genes was done based on similarity with Arabidopsis set of proteins v. 2.0 present at MIPS (Munich Information Center for Protein Sequence, http://mips. gsf.de/proj/funcatDB/search_main_frame.html) using the BlastX tool.

\section{Results and Discussion}

\section{Plant inoculation}

The presence and viability of $X$. fastidiosa artificially inoculated into the plants has been used as an approach to monitor the efficacy of the inoculation and to verify whether the plant withstands the pathogen. Here, the presence of $X$. fastidios $a$ in inoculated tissues was analyzed by PCR with specific primers and isolated on PW medium (Table 1). After two weeks, inoculation positive amplifications were detected in 'Ponkan' mandarin and 'Pera' sweet orange. Four to eight weeks after inoculation, all plants were positive for $X$. fastidiosa. However, positive isolation of bacteria was possible only for inoculated sweet orange plants, which showed initial CVC symptoms 5 months after inoculation. On mandarin, after inoculation, it is possible that the bacteria started growing but failed to colonize the vessels, resulting in a decrease of the population and, consequently, death. However, this hypothesis needs to be proven.

\section{In silico analyses and functional annotation}

A total of 19,200 EST sequences was used in the bioinformatics analysis. Of these, 17,695 met satisfactory quality standards, corresponding to 350 nucleotides of Phred quality score of 20 or above. For a score of 20, the accuracy of the base calling is $99 \%$ (Ewing and Green, 1998). The sequences were subsequently used in clustering, generating 7,814 contigs and 4,635 singlets after assembly. Through an in silico differential display, we found 152
Table 1 - PCR and recovery of $X$. fastidiosa from artificially inoculated plants of 'Pera' sweet orange and 'Ponkan' mandarin.

\begin{tabular}{|c|c|c|c|c|}
\hline \multirow{2}{*}{$\begin{array}{l}\text { Plant } \\
\text { inoculation }\end{array}$} & \multicolumn{3}{|c|}{ PCR results ${ }^{1}$ weeks after inoculation } & \multirow{2}{*}{$\begin{array}{l}\text { X. fastidiosa } \\
\text { recovery }^{2}\end{array}$} \\
\hline & 2 & 4 & 8 & \\
\hline Ponkan 1 & ++ & ++ & ++ & - \\
\hline Ponkan 2 & - & ++ & ++ & - \\
\hline Ponkan 3 & ++ & ++ & ++ & - \\
\hline Ponkan 4 & ++ & ++ & ++ & - \\
\hline Ponkan mock & - & - & - & - \\
\hline Pera 1 & - & ++ & ++ & ++ \\
\hline Pera 2 & - & ++ & ++ & ++ \\
\hline Pera 3 & ++ & ++ & ++ & ++ \\
\hline Pera 4 & ++ & ++ & ++ & ++ \\
\hline Pera mock & - & - & - & - \\
\hline
\end{tabular}

${ }^{1} X y l e l l a$-specific amplification products from plant inoculated samples collected at two, four and eight weeks after inoculation: $(+)$ positive amplification; (-) negative amplification.

${ }^{2}$ Recovery of Xylella fastidiosa, from plant inoculated tissues, on PW medium at 11 weeks after inoculation: $\mathrm{P}$ - successful bacteria recovery; $\mathrm{N}$ unsuccessful bacteria recovery.

genes to be significantly differentially expressed ( $\mathrm{p} \leq 0.05)$. In this comparison, 81 and 71 putative genes showed higher expression in mandarin and sweet orange infected plants at 30 days after inoculation (dai), respectively.

We categorized the significant contigs into functional groups based on the MIPS Arabidopsis gene functional categories. The functional categories and distributions of the genes differentially expressed in mandarin and sweet orange are shown in Figure 1. Evaluation of mandarin and sweet orange ESTs showed distribution of putative genes in 15 functional categories with emphasis in five, namely: i. Metabolism; ii. Energy; iii. Cellular transport, transport facilitation and transport routes; iv. Cell rescue, defense and virulence; and v. Proteins with unknown function.

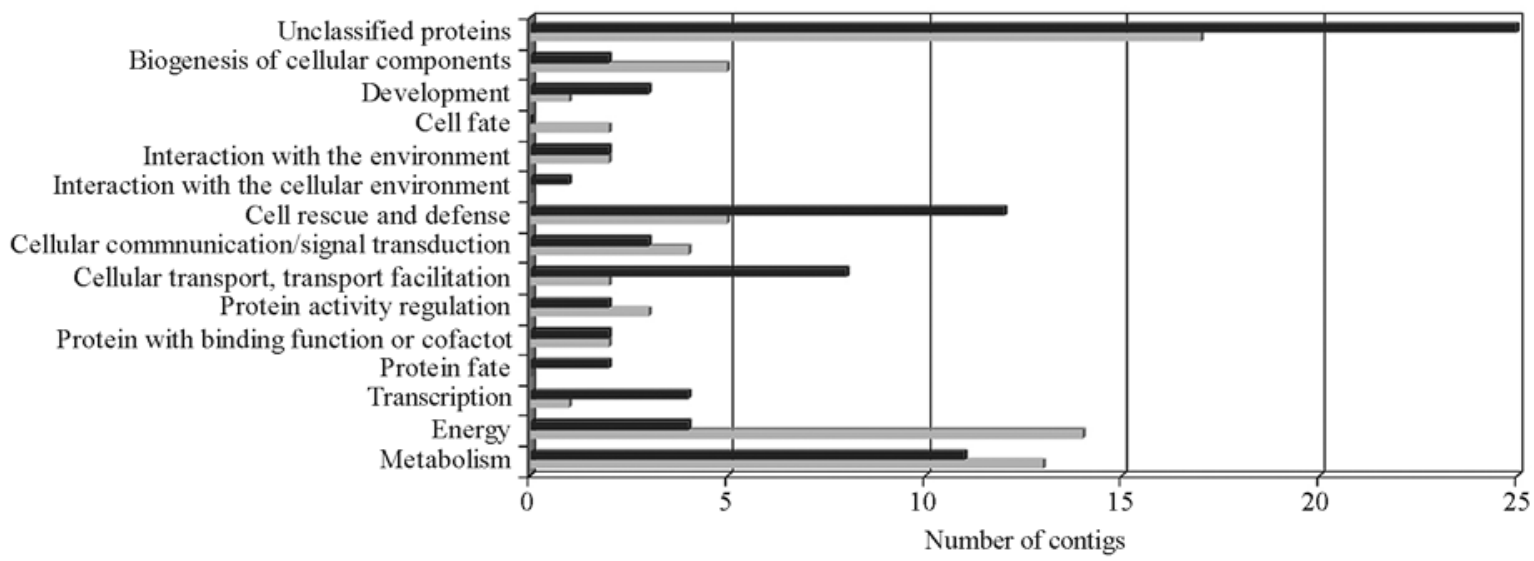

Figure 1 - Number of significant contigs distributed in functional categories of the mandarin (black) and sweet orange (gray) libraries infected with $X$. fastidiosa. 


\section{Functional categorization and comparative analysis of Sweet Orange and Mandarin}

The functional category of putative genes related to energy had the highest number of differentially expressed genes in sweet orange compared to mandarin. This category includes mainly genes associated with photosynthesis (Table 2). No typical chlorosis could be observed in the leaves of plants infected with $X$. fastidios $a$ at 30 DAI. This could eventually explain the increase in the expression of genes associated with photosynthesis as a response to chlorophyll degradation. Nevertheless, studies on the physiology of sweet orange plants infected with $X$. fastidiosa showed that even without development of typical symptoms of chlorosis it was possible to verify early effects of the bacteria on photosynthesis, with a reduction in the activity of the photosynthetic apparatus (Ribeiro et al., 2003). Our results showed that the infection by X. fastidiosa, besides blocking the xylem vessels in the later phase of the disease, induced the expression of several genes responsible for synthesis of important components of the photosynthetic apparatus (Table 2). The higher expression of such genes could be correlated with a de novo synthesis of redox photosynthesis machinery as a mechanism to counterbalance the lower photosynthetic activity resulting from the early effects of the bacterial colonization in susceptible plants. In later stages of the infection, chlorosis is observed in sweet orange and a decrease in transcription of photosynthesis related genes is observed (Souza et al., this issue). This reinforces the idea that the expression of these genes in early stages of the infection is an attempt to maintain the physiological functions at an adequate level.

In mandarin, the most significant functional category was Cell rescue, defense and virulence (Figure 1). Because this species is resistant to $X$. fastidiosa, the expression of these genes in this organism suggests that they may have an important role in resistance. The genes significantly expressed in mandarin that are possibly associated with defense response to the pathogen are listed in Table 3 .

In mandarin we found one gene encoding an NBSLRR-like disease resistance protein and a second coding for multidomain cyclophilin type peptidyl-prolyl cis-trans isomerase. It has been recently demonstrated that the later protein activates the avirulence protein AvrRpt2 from Pseudomonas syringae in incompatible interaction with Arabidopsis thaliana, leading to RPS2-mediated resistance and providing evidence for the 'guard hypothesis' (Coaker et al., 2005). These proteins are normally involved in responses in which avirulence proteins from the pathogens are involved. However, neither homologues of avr genes nor their type III secretion apparatus were identified in the $X$. fastidiosa genome. A possible explanation for the inducible mechanisms activated in mandarin in response to $X$. fastidiosa can be given from a perception of general elicitors 'non-self' or PAMPs (pathogen-associated molecular pattern). This is the basis for the non-host resistance, where general elicitors derived from pathogens activate signaling pathways leading to gene expression and consequently, resistance (Ingle et al., 2006).

Table 2 - Up-regulated genes in sweet orange infected with $X$. fastidiosa observed in the most relevant functional category.

\begin{tabular}{|c|c|c|c|}
\hline $\begin{array}{l}\text { MIPS functional } \\
\text { category }\end{array}$ & p- value ${ }^{1}$ & Best blast match & NCBI number ${ }^{2}$ \\
\hline \multirow[t]{13}{*}{ Energy } & 0.01 & Pyruvate decarboxylase-1 Pdc1 (Arabidopsis thaliana) & $\mathrm{gb} \mid \mathrm{AAM} 674591$ \\
\hline & 0.01 & Ribose 5-phosphate isomerase (Arabidopsis thaliana) & gb|AAF049051| \\
\hline & 0.003 & Photosystem II polypeptide (Arabidopsis thaliana) & $\mathrm{gb}|\mathrm{AAM} 201941|$ \\
\hline & 0.004 & 33 kDa polypeptide of water-oxidizing complex of photosystem II (Nicotiana tabacum) & emb|CAA457011| \\
\hline & 0.002 & 22kD-protein of photosystem II (Spinacia oleracea) & emb|CAA485571| \\
\hline & 0.001 & $\begin{array}{l}\text { Oxygen-evolving enhancer protein 2, chloroplast precursor (OEE2) ( } 23 \mathrm{kDa} \text { subunit of oxygen } \\
\text { evolving system of photosystem II) (OEC } 23 \mathrm{kDa} \text { subunit) ( } 23 \mathrm{kDa} \text { thylakoid membrane pro- } \\
\text { tein) (OEC23) (Cucumis sativus) }\end{array}$ & sp|Q9SLQ8| \\
\hline & 0.0009 & Photosystem I subunit V precursor (Arabidopsis thaliana) & gb|AAK003741| \\
\hline & 0.00002 & Ribulose-1,5-bisphosphate carboxylase/oxygenase activase 1 (Gossypium hirsutum) & gb|AAG611201| \\
\hline & 0.01 & Chlorophyll a/b-binding protein CP24 precursor (Vigna radiata) & $\mathrm{gb}|\mathrm{AAD} 278822|$ \\
\hline & 0.006 & Chlorophyll a/b-binding protein precursor (Citrus limon) & $\mathrm{gb}|\mathrm{AAO} 458851|$ \\
\hline & 0.002 & Chlorophyll a-b binding protein, chloroplast precursor (LHCI type II CAB) (Petunia x hybrida) & $\operatorname{sp}|\mathrm{P} 13869|$ \\
\hline & 0.0001 & Phosphoribulokinase, chloroplast precursor (Mesembryanthemum crystallinum) & $\operatorname{sp}|\mathrm{P} 27774|$ \\
\hline & 0.0 & Plastidic aldolase (Nicotiana paniculata) & dbj|BAA776031| \\
\hline
\end{tabular}

${ }^{1}$ Probability of having the putative gene differentially expressed only by chance (significant for $\mathrm{p}<0.05$ ).

${ }^{2}$ http://www.ncbi.nlm.nih.gov/. 
Table 3 - Up-regulated genes in mandarin infected with X fastidiosa observed in the most relevant functional category

\begin{tabular}{|c|c|c|c|}
\hline MIPS functional category & p- value ${ }^{1}$ & Best blast match & NCBI number ${ }^{2}$ \\
\hline \multirow{11}{*}{$\begin{array}{l}\text { Cell rescue, defense } \\
\text { and virulence }\end{array}$} & 0.004 & NBS-LRR type disease resistance protein (Poncirus trifoliata) & gb|AAN623501| \\
\hline & 0.01 & Peptidyl-prolyl cis-trans isomerase cyclophilin-type family protein ( $A$. thaliana) & ref|NP_1949682| \\
\hline & 0.0001 & S-adenosyl-L-methionine:salicylic acid methyltransferase (Antirrhinum majus) & gb|AAN407451| \\
\hline & 0.0005 & Lipoxygenase (Nicotiana attenuata) & gb|AAP831371| \\
\hline & 0.008 & Peroxidase (Gossypium hirsutum) & gb|AAA998681| \\
\hline & 0.004 & Fe-superoxide dismutase precursor (Medicago sativa) & gb|AAL324411| \\
\hline & 0.003 & Annexin (Arabidopsis thaliana) & $\mathrm{gb} \mid$ AAM647501| \\
\hline & 0.002 & Cytochrome p450 protein (Arabidopsis thaliana) & emb $\mid$ CAB799151| \\
\hline & 0.01 & Cytochrome p450 protein (Arabidopsis thaliana) & gb|AAK937091| \\
\hline & 0.01 & Dehydration-induced protein RD22-like protein (Gossypium hirsutum) & gb|AAL679911| \\
\hline & 0.01 & DnaJ-1 (Cucumis sativus) & emb|CAA479251| \\
\hline
\end{tabular}

${ }^{1}$ Probability of having the putative gene differentially expressed only by chance (significant for $\mathrm{p}<0.05$ ).

${ }^{2}$ http://www.ncbi.nlm.nih.gov.

A gene encoding lipoxygenase (LOX) was induced by $X$. fastidiosa in mandarin. LOX is the key enzyme in the synthesis of jasmonic acid (JA), catalyzing the production of JA from linoleic acid, which stimulates the expression of defense-related genes functioning as secondary signals that activate a subset of defense genes. We also found one gene encoding S-adenosyl-L-methionine:salicylic acid methyltransferase. This gene is responsible for the synthesis of methyl salicylate, which is a plant-signaling compound of the salycilic acid (SA) pathway that activates defense responses (Deng et al., 2005). The presence of two different precursor enzymes of two signal compounds, JA and SA, may indicate crosstalk among regulatory pathways controlling different cellular processes in mandarin during the interaction with $X$. fastidiosa. Some genes associated with defense and related to the oxidative burst were also detected in our study. Among them there are genes that encode antioxidant enzymes, such as peroxidase, Fesuperoxide dismutase and annexin. The identified annexin is similar to the Arabidopsis thaliana annexin 1, which possesses peroxidase activity, limiting excessive levels of reactive oxygen species during the oxidative burst (Gorecka et al., 2005). Oxidative Burst is a common mechanism that occurs both in abiotic and biotic stresses. Genes involved with abiotic stress were found to be up-regulated in mandarin infected with $X$. fastidiosa, including those encoding DnaJ and RD22 proteins. DnaJ is a chaperone that functions in protein folding and marks incorrectly folded proteins for turnover (Bohnert et al., 1995). Despite the increase in their expression that occurs during the abiotic stresses, induction in the synthesis of chaperones has also been observed in responses to pathogen attack as well (Jelitto-Van Dooren et al., 1999). The RD22 protein acts in detoxification of oxidative stressors produced under water deficit (Abe et al., 1997; Gillet et al., 1998).

Genes encoding cytochrome p450 were also induced in mandarin by $X$. fastidiosa. Plant P450s are involved in the biosynthesis of secondary products (phenylpropanoids, alkaloids, terpenes, lipids, cyanogenic glycosides and glucosinolates), which give important properties to plants, such as flavor, color and herbivore/pathogen resistance (Bolwell et al., 1994; Schuler, 1996). Moreover, plant P450s are also essential in the biosynthetic pathways of plant growth regulators, including gibberellins, brassinosteroids and jasmonic acid, and in detoxification processes. Many of the bestcharacterised P450s are inducible enzymes, involved in xenobiotics detoxification, and have relatively broad substrate specificity (Paquette et al., 2000). Since one of the virulence factors of $X$. fastidios $a$ is the production of toxins and in its genome were found genes encoding toxins and antibiotic production (Simpson et al., 2000), it is reasonable to suppose that this protein could be actively working in the detoxification of these factors.

Several contigs sharing homology with unclassified Arabidopsis genes and others for which no similarities could be found with sequences from any database were found to be induced within the mandarin plants after infection with $X$. fastidiosa. This finding may help to elucidate the function of the proteins encoded by them.

The activation of all these genes in mandarin may be part of the defense response mechanisms against pathogens. Moreover, several genes related to cellular transport, transport facilitation and transport routes, specific proteins and transcriptional factors were also induced in mandarin plants inoculated with $X$. fastidiosa.

The response of mandarin to $X$. fastidiosa seems to include features of the non-host resistance, with activation of the gene expression through the recognition of non-specific elicitors. This activation includes two different signaling pathways, the jasmonate and the salycilic acid pathways, which ultimately leads to synthesis of resistance components. In the responses, the production of reactive oxygen species (ROS) leading to the production of detoxifying proteins appears to exist. Another characteristic of this resistance seems to be the production of proteins that are responsible for fighting the toxins or antibiotics probably 
produced by the bacterium and that could cause damage to the plant. Therefore, our study suggests that different defense responses are taking place in mandarin in the interaction with $X$. fastidiosa in a multifactor antipathogen response. This hypothesis should be verified by further functional experiments.

\section{In silico analysis of the species-specific genes associated with $X$. fastidiosa response}

The in silico hybridization using two different species, Citrus reticulata and Citrus sinensis, can generate clusters that are specific to each of the species. This can affect the analysis of differential gene expression which is based on clustering of ESTs. Therefore, the clusters containing reads from only one of the species were further analyzed by searching for homologues in either Citrus sinensis or Citrus reticulata. This analysis was performed using the Blastn tool (Altschul et al., 1997). As a result, homologues for all analyzed genes were found in the comparing species, showing that only the expression levels in the different libraries were different.

Some changes in gene induction/repression were observed when comparing the susceptible and resistant Citrus species. Many genes were observed to be up- or downregulated upon X. fastidiosa infection. An examination of a wider range of hybrid between Citrus sinenesis and Citrus reticulata could answer the question of whether our findings represent a general feature of the Citrus- $X$. fastidiosa interaction, which might also lead to development of helpful markers for Citrus breeders. In order to complete the information on the function and nature of the genes that respond to $X$. fastidiosa infection, studies on the protein level as well as on silencing and over-expression of candidate genes will be helpful.

\section{Acknowledgments}

The research was supported by Conselho Nacional de Desenvolvimento Científico e Tecnológico (CNPq, Instituto do Milênio). A.A.S., M.A.T., H.D.C-F., M.L.P.N.T. and M.A.M. are recipient of a research fellowship from CNPq.

\section{References}

Abe H, Yamaguchi-Shinozaki K, Urao T, Iwasaki T, Hosokawa D and Shinozaki K (1997) Role of arabidopsis MYC and MYB homologs in drought- and abscisic acid-regulated gene expression. Plant Cell 9:1859-68.

Altschul SF, Madden TL, Schaffer AA, Zhang J, Zhang Z, Miller W and Lipman DJ (1997) Gapped BLAST and PSI-BLAST: A new generation of protein database search programs. Nucleic Acids Res 25:3389-402.

Audic S and Claverie JM (1997) The significance of digital gene expression profiles. Genome Res 7:986-995.

Bohnert HJ, Nelson DE and Jensen RG (1995) Adaptations to environmental stresses. Plant Cell 7:1099-1111.
Bolwell GP, Bozak K and Zimmerlin A (1994) Plant cytochrome P450. Phytochemistry 37:1491-1506.

Coaker G, Falick A and Staskawicz B (2005) Activation of a phytopathogenic bacterial effector protein by an eukaryotic cyclophilin. Science 22:548-50.

Davis MJ, French WJ and Schaad NW (1981) Axenic culture of the bacteria associated with phony disease of peach and plum leaf scald. Curr Microbiol 6:309-314.

Deng C, Qian J, Zhu W, Yang X and Zhang X (2005) Rapid determination of methyl salicylate, a plant-signaling compound, in tomato leaves by direct sample introduction and thermal desorption followed by GC-MS. J Sep Sci 28:1137-1142.

Ewing B and Green P (1998) Base-calling of automated sequencer traces using phred. II. Error probabilities. Genome Res 3:186-194.

Ewing B, Hillier L, Wendl M and Green P (1998) Basecalling of automated sequencer traces using phred. I. Accuracy assessment. Genome Res 8:175-185.

Fernandes-Jr WB (2003) Analysis of the World Processed Orange Industry. Ph.D. Thesis. University of Florida, Gainesville, 108 pp.

Gillet B, Beyly A, Peltier G and Rey P (1998) Molecular characterization of CDSP 34, a chloroplastic protein induced by water deficit in Solanum tuberosum L. plants, and regulation of CDSP 34 expression by ABA and high illumination. Plant J 16:257-262

Gorecka KM, Konopka-Postupolska D, Hennig J, Buchet R and Pikula S (2005) Peroxidase activity of annexin 1 from Arabidopsis thaliana. Biochem Biophys Res Commun 28:868-875

Ingle RA, Carstens M and Denby KJ (2006) PAMP recognition and the plant-pathogen arms race. Bioessays 28:880-889.

Jelitto-Van Dooren EP, Vidal S and Denecke J (1999) Anticipating endoplasmic reticulum stress. A novel early response before pathogenesis-related gene induction. Plant Cell 11:1935-1944.

Lee S, Kim SY, Chung E, Joung YH, Pai HS, Hur CG and Choi D (2004) EST and microarray analyses of pathogen-responsive genes in hot pepper (Capsicum annuum L.) non-host resistance against soybean pustule pathogen (Xanthomonas axonopodis pv.glycines). Funct Integr Genomics 4:196-205.

Machado EC, Quaggio JA, Lagôa AMMA, Ticelli M and Furlani PR (1994) Trocas gasosas e relações hídricas em laranjeiras com clorose variegada dos citros. Rev Bras Fisiol Veg 6:5357.

Murray MG and Thompson WF (1980) Rapid isolation of high molecular weight plant DNA. Nucleic Acids Res 8:43214325.

Oliveira RP, Cristofani M and Machado MA (2005) Integrated genetic map of citrus based on RAPD markers. Fruits 60:187-193

Paquette SM, Bak S and Feyereisen R (2000) Intron-exon organization and phylogeny in a large superfamily, the paralogous cytochrome P450 genes of Arabidopsis thaliana. DNA Cell Biol 19:307-317.

Pooler MR and Hartung JS (1995) Specific PCR detection and identification of Xylella fastidiosa strains causing citrus variegated chlorosis. Curr Microbiol 31:377-381.

Ribeiro RV, Machado EC and Oliveira RF (2003) Early photosynthetic responses of sweet orange plants infected with Xylella fastidiosa. Physiol Mol Plant Pathol 62:167-173. 
Schuler MA (1996) The role of cytochrome P450 monooxygenases in plant - Insect interactions. Plant Physiol 112:1411-1419.
Simpson AJG, Reinach FC, Arruda P, Abreu FA, Acencio M, Alvarenga R, Alves LMC, Araya JE, Baia GS and Baptista CS (2000) The genome sequence of the plant pathogen Xylella fastidiosa. Nature 406:151-159.

Associate Editor: Reinaldo Montrazi Barata 